\title{
A Political Theory Approach to Understanding Conflict in Selected African States
}

\author{
Solomon Owuoche \\ Department of Political Science and Public Administration, University of Nairobi, Nairobi, Kenya \\ Email: solomon.owuoche@uonbi.ac.ke
}

Received 27 January 2015; accepted 12 February 2015; published 16 February 2015

Copyright (C) 2015 by author and OALib.

This work is licensed under the Creative Commons Attribution International License (CC BY). http://creativecommons.org/licenses/by/4.0/

(c) (i) Open Access

\begin{abstract}
Conflict remains a constant, but not a permanent factor, in many African states today. For many decades we have witnessed perpetual conflicts in African states, a characteristic that has led to African states being referred to as dark, anarchical, insecure and violent, particularly as compared to other states and regions of the world. Many studies and researchers have developed frameworks on the likely factors that explain conflict in Africa although there seems to be lack of agreement as to the actual cause of conflicts among the mentioned causes, but are not limited to tribal and clan differences, xenophobia, religious extremism, gender-based violence and resourcebased conflict. It is this clear lack of a grand theory that has led to paradigmatic competitors, with each presenting its own understanding of the problem of conflict. This article adopts a political theory approach to understand conflict by drawing examples from selected African states. From the selected examples it is clear that the mentioned states have not played their roles effectively in protecting life and property due to various challenges. Some of the reasons forwarded for the failure by state to protect life and property include the issues of a lame Leviathan and the mentioned states' inability and failure to appreciate that there are no limits to an individual's evilness. The main argument is that those individuals who refuse to live in line with the public good should ideally be compelled by the state to "see the light". But what happens when the very state is weak and incapable of undertaking this cardinal responsibility? The article develops a framework within which conflict within the state may be understood with a view to improve the ability of the state in enhancing security at national, regional and international levels.
\end{abstract}

\section{Keywords}

Conflict, Security, Africa

Subject Areas: History, Politics, Sociology 
Man's passion for war is stronger but the adverse effects of war makes men to reason and seek peace.

-Paraphrased from The Leviathan by Thomas Hobbes, 2009, Chapter 14 [1]

It is a small matter than the creation of South Sudan. I know we shall find a solution... It is part of human nature that there is an element of selfishness.

-Former Kenyan President Mwai Kibaki commenting on the South Sudan conflict, Daily Nation, $9^{\text {th }}$ April 2014, 8 [2]

\section{Introduction}

There is a prevailing argument that conflict is attributable to mutually incompatible goals. Conflict occurs where there are competing roles. In almost all cases, conflict is primarily over resources. Any political, economic and social system implies an allocation of power, wealth and status among individual actors and component groups. There is no complete concordance between what individuals and groups within a system consider just due to the system of allocation. Conflict ensures the efforts of various frustrated groups and individuals to increase their share of gratification. Their demands are bound to encounter the resistance of those who have established "vested interests" in a given form of distribution of honor, wealth, power and authority. To those with "vested interests", an attack against the social order is an attack upon the system itself. Conflict signifies a disturbance in equilibrium or status quo.

Many believe that when we engage in conflict it will be short and that more often than not the aggressor will win the conflict. But how true is this assumption? A critical look at selected African states reveals that this optimism is largely misplaced. Many of the conflicts that have been experienced in Africa are long conflicts whose durations have been variously explained. The point is that the initial optimism that accompanies the beginning of a conflict quickly evaporates. Several explanations may be offered for this state of affairs. This article calls for a re-examination of the probable causes of conflict in Africa while reasserting that the answer is to be found in political theory. Therefore, a good starting point in analyzing the African situation is to look at the nature of man and the duties of the state.

\section{The Nature of Man}

St. Augustine (2003) [3], a prolific African philosopher, argues that man is created in God's image; the image of goodness. This striking association between God and man does not in any way place certain inhibitions on man. Man is independent and deliberately decides on their own destiny; a path of doing good (City of God) or a path of doing evil (City of Sin). In capturing the nature of man, St. Augustine (2003) [3] sees man as being involved in a gigantic struggle of history; whereby man is always faced with a dilemma on either to do good or pursue the destructive path of injuring thy neighbour. More often than not, man's evil side prevails. Unlike St. Augustine who emphasises that man is an "image of God", Edmund Burke (1955) [4] is of the opinion that God made man imperfect. It is this imperfect image of man that explains the existence of evil (conflict) in the world. This line of argument had earlier been raised by Aristotle (1981) [5] and was later on developed by Thomas Hobbes (2009) [6] and John Locke (1960) [7]. It is Aristotle who said that man without law is a "beast". This was modified by Hobbes and Locke who argue that man without society is a savage. This provides a basis on whether the absence of security or existence of insecurity, is a failure by the state to reign in man's evil nature.

Hobbes (2009) [8] sees man as hopelessly evil. In what is popularly referred to as the Hobbesian state of nature, man was wicked, selfish and with limited level of human rationality. To Hobbes, life in the state of nature is "solitary, brutish, and short”. It is this absence of rationality that strengthens man's passion for war. Man will resort to war, anarchy and destruction as a way of resolving issues. By leaving the state of nature, man deliberately becomes a society man and agrees to be “moral”. As noted by Burke (1955) [9], society improves man by being a source of morality. It is these morals that control the appetite of man. The issue therefore is whether society has been able to tame the appetite of man. From this discussion the following questions arise: Has man agreed to be moral? Does man respect the rights of others to exist? Does man recognise the rights of state to control their behavior so as to live in peace with others?

Hobbes (2009) [10] opines that for man to co-exist with others, there is need for external guarantees. Man will always be guided by self-interest so that any situation that threatens their existence will be avoided. To contextualise the actions of man, it becomes necessary to have an all powerful, omniscient, omnipresent and comprehensive state. The state must have absolute power over the subjects. It is in the state that effective power lies. 
The state is like a conqueror that has absolute power over the conquered-and it is in the interest of the conquered to submit to the powers of the conqueror. Those who refuse to submit to the powers of the conqueror only have themselves to blame for the conqueror will not have any mercy for such. In this case the conqueror is like a prince as was envisaged by Niccolo Machiavelli (1952) [11]. The conqueror makes laws that must be obeyed by all the subjects. The laws are cast in stone like the biblical "Ten Commandments". In other words, enshrined in the laws is the element of power that guarantees that all the laws are obeyed. The subjects "consent" when they promise obedience to the conqueror, who then promises not to kill, murder or assassinate the subjects. But is this a license for the conqueror/prince/governor to intimidate and deal with the subjects ruthlessly? What happens when the conqueror turns against his people? Who do the people turn to for security of their property and lives? To address the issues raised above, we now draw lessons from selected African states.

\section{Liberia under Charles Taylor}

For many years Charles Taylor was a feared war-lord. In the 1997 general elections in Liberia, Charles Taylor, then a presidential candidate, spread fear among the populace. His campaign slogan was itself bloodletting, "He killed my ma, he killed my pa, but I will vote for him” (http://www.bbc.com/news/world-africa-12392062, $24^{\text {th }}$ April 2014) [12]. This slogan was very similar in tone to that of George Bush Jr. who after the terrorist events of September 11, 2001 in the USA, argued that "You are either with us, or you are against us". Since the events of September 11 the phrase has become associated with George Bush Jr. who during his address to a joint session of Congress in September 20, 2001 uttered the words, "Either you are with us or you are with the terrorists". It became a rallying point in the fight against terrorism. But the main point of departure was that Bush Jr. was reassuring the populace that his government would employ its entire arsenal to guarantee security for its citizens while on the converse, Taylor was threatening the same subjects he was supposed to protect. Taylor ran a campaign that required the populace to be totally subservient and beholden to him. His argument was that a vote for him was a vote for peace and stability in Liberia. On the contrary, a vote against him was a guarantee for anarchy and bloodshed that paradoxically would be conducted under his command. It is based on apprehension and coercion that Taylor was elected as President of Liberia garnering over 75 per cent of the popular vote. Further to this, the exploits of Taylor, convicted by the Special Court for Sierra Leone for bearing the greatest responsibility for war crimes in Sierra Leone, where he financed and supported the rebel movement Revolutionary United Front (RUF), was akin to the "Jacobin Reign of Terror". This is in reference to the French Revolution of 1789. During this period those perceived as either counter-revolutionary or anti-revolution were persecuted and killed. It is estimated that over 40,000 people died between 1789 and 1794. The RUF was led by a war-lord called Foday Sankoh. Sankoh was also indicted for crime against humanity on 7 March 2003 by a Special Court for Sierra Leone. The RUF was well known for two things: firstly, misusing the diamond wealth of Sierra Leone to sustain its war against the democratically elected government of Ahmed Tejan Kabbah and, secondly, committing war crimes against the citizenry. RUF was accused of sadistic tendencies that included using child soldiers, adducting women and children and using them as sex slaves and cutting off civilian limbs to score a propaganda victory and make a mockery of the then elected government of Kabbah, who had campaigned on an election slogan "The future is in your hands" (Karon, 2000) [13]. In the mind of the RUF leader, chopping off the hands of the civilians was a lesson to the civilians to desist from supporting the government. What issues arise from the Liberian/Sierra Leone scenario? These are issues we now turn to.

\section{Right of State to Protect Factor}

First and foremost, the sole responsibility of any government is to protect both the individual and the commonwealth from both internal and external threats. This line of thinking was clearly captured by John Locke (1960) [14] who, while noting that all governments are founded on the consent of the governed, also went further to state that the governor and the government must protect the life and property of the governed. Any government that is not able to perform this cardinal role should ideally come to an end. It is Locke who pointed out that in the evident that the government fails to protect the life and property of the individual and society, then it is within the rights of the governed to resist. In other words, the governed have the right to appeal to God or the gods to send a revolution. For the absence of security for the individual and the community is a breach of the contract between the governor and the governed; therefore negating the right of the state to govern. John Stuart Mill (1946) [15] echoes the same point when he argues that the community is within its right to check upon the 
powers of the government. If the leaders govern badly, then the community has the power to dismiss its rulers through periodic elections. It is along these lines that we argue that in the contemporary society "appealing for a revolution" may not be necessary for there are structures that have been put in place to guarantee that the leaders are more responsive to the needs of the people. In a democratic state, leaders are subjected to periodic elections where the people determine policy, leaders and law. It is through elections that those who do not measure to the people's preferences do not get a new mandate while those who perform are offered a new mandate by the electorate.

\section{Failed Leadership Factor}

A second point to consider is, what happens when the leaders or those who ascend to positions of responsibility who do not account to the citizens? There are times when the government and the leaders, mandated on issues of security, turn against the citizens. In such a situation, the leaders are more concerned about self preservation and will therefore do whatever is within their means to even attain, maintain, and even increase power. For such leaders, power is a means to an end and the end justifies the means. The same citizens that should be protected become the targeted population. Empirical evidence shows that in some cases the government (leaders) has had cordial relations with Faith-Based Organizations (FBOs) whose agenda is to intimidate and persecute the citizens. The government of Sudan has over the years supported the Arab militia called Janjaweed that operates in the Darfur region. This militia has over the years employed violence with a view to getting unlimited access to the Darfur region for their animals to graze. This has put them into conflict with the largely Christian South Sudan population. The aid that the militia receives from the Sudan government has escalated the conflict leading to the displacement of over one million people and thousands of reported deaths. The Sudan government and Janjaweed appear to share a common agenda of "anti-Christianity" and "anti-black farmers" that has led to the creation of a very unstable region.

\section{The Evilness of Man Factor}

Thirdly, there are no limits to man's cruelty and bad behaviour, provided they can get away with it (Hobbes, 2009) [11]. Men are capable of magnificent evil. It is within this context that the state sometimes steps in to compel the individual to live up to the society's expectations. If an individual ignores societal rules and behaviour patterns then it is the right of the state and leader to "force the individual to be free" (Rousseau, 1979) [16]. The individual maybe incarcerated or removed from society for a period of time; until that time that they fully reform and are fit to be re-absorbed into society. The Rwanda Genocide of 1994 where an estimated 800,000 Tutsis and moderate Hutu lost their lives in one of the most horrific ethnic cleansing to have been witnessed in the world. Those found to have participated in the genocide received long jail terms. Those who confessed in public of their involvement in crimes against humanity received reduced jail terms and some were freed conditionally with a view to promoting healing and reconciliation with their neighbours. It is worth noting that details of the Rwanda Genocide of 1994 have been captured by various authors. A more graphic account of the genocide was captured by Immaculee Ilibagiza in her work Left to Tell..., 2007 [17]. Reference can also be made to the Bentiu Massacre in South Sudan in April 2014 were over 400 children, women and unarmed civilians lost their lives to armed militias. The attack was ethnically motivated with the massacred committing the "sin" of belonging to the "wrong tribe".

Machiavelli (1952) [12] had earlier on suggested more drastic measures to be taken against individuals who refuse to comply with societal rules and values. Since such persons threaten the survival of the state, it is the prerogative of the Prince (leader) to employ whatever means at their disposal to eliminate such threats. Machiavelli recommends a range of measures be taken by the Prince including assassinations, murder, killings and eliminations of the perceived threats. All these must be done in the interest of the state. For the Prince guarantees the survival and cohesion of the state. Given the options that the state has at its disposal, the state must therefore be held to account on matters to do with security.

In an ideal situation, it is the state that has monopoly over force. This force is used to protect the individual and the commonwealth in the enjoyment of their property (Cicero, 1960) [18]. This line of argument was earlier propagated by Max Weber (1922) [19] who opine that the state must have monopoly over violence for it to have effective control over the citizens. Likewise, Hobbes underscores the absoluteness of the state as a guarantee that man lives in harmony with others. But what happens when the situation is not ideal as is the case with Af- 
rica? In Africa, the state's "monopoly over force” is more of a mirage, with many other non-state actors challenging the sole right of state to provide security. For example, in Nigeria we have the Boko Haram that has challenged the right of the state to dominate violence. Boko Haram is an Islamist militant group that was formed in 2009 and mainly operates in the Northern parts of Nigeria. Its main aim is to overthrow the elected government of Nigeria and replace it with an Islamic Sharia state. The same applies to Kenya with the existence of many pressure groups such as Chinkororo, Mungiki, Taliban, Jeshi la King'ole, Kamjeshi, Baghdad Boys, Mombasa Republican Council (MRC), Sabaot Land Defence Force (SLDF), among others, which have over the years proved to be a security nightmare for the state. These groups remain banned in Kenya but continue to harass and intimidate the populace. In Somalia the situation is even more critical with the absence of political centralisation. What we have are people organized in clan families and who owe their allegiance, not to the government based in Mogadishu, but to the head of the clan. The consequence is clan rivalry over resources, power and with "nobody respecting the authority of the other" (Acemoglu and Robinson, 2013: 241) [20].

\section{Sovereignty Factor}

There exist some cases that show that the state may be willing to protect the individuals and their property but might not be in a position to guarantee security as in the case of Sierra Leone. The government of Kabbah appeared helpless with the advancement of the rebel movement RUF. It is within this context that the Economic Community of West African States Monitoring Group (ECOMOG) led by Nigeria intervened and arrested the rebel leader Sankoh. ECOMOG was a multi-lateral armed force that brought together a number of national armies, led by Nigeria. Other members were Gambia, Nigeria, Burkina Faso, Mali, Liberia, Niger and Sierra Leone among others. It emerged from the anarchy that characterised Liberian politics. It aimed at regional peace. The government's move to invite a foreign military force to protect the citizens can be looked at from different view-points: firstly it was an admission by government that it had failed to protect the citizens. The government doubted its supremacy in matters of security and could therefore not lead from the front therefore going against the "thumb rule" that all aspects of security are subject to the intervention of the state, which reserves the right to provide final judgments on matters of security. This argument is premised on Jean Bodin (1992) [21] and Harold Laski's (1917) [22] conceptualisation of sovereignty-that sovereignty cannot be shared, for it is inalienable, whole, and indivisible and anything that smacks of division is not sovereign. The people are subordinate to the state and will therefore expect to be defended by the state. Any state that is not capable of playing this significant role, according to Georg Fredrich Wilhelm Hegel (1988) [23], is barbaric and must come to an end. A foreign force equals to weak leadership with the consequence being that the legitimacy of government is questioned and the sovereign right of government to govern effectively is no more. The issue of what to give and what not to give within the context of regional integration is not peculiar to Africa. The membership of the European Union (EU) and North Atlantic Treaty Organization (NATO) has over the years been uncomfortable with surrendering their security and defence to the regional bodies. The argument is that issues of security are so central and unique and it would be wrong to apply uniform standards to all. This explains, to a large extent, the reluctance by many European states to surrender their security to either NATO or the EU. And the positions of states to be in charge of their security has been re-enforced by the Ukrainian crisis where the EU, NATO and even the world's only super power, the United States of America (USA) have appeared powerless to intervene to insulate Ukraine from Russia's overt and covert military operations. Ukraine has over the years accused Russia of undermining its sovereignty by offering support to rebels who operate mainly in the southern and eastern parts of Ukraine. Russia argues that it has a right to protect its Black Sea Fleet, a branch of the Russian Navy from any form of threat, particularly by EU and NATO that appear fixated with expansion eastwards to curtail Russian influence.

Secondly is that the state understands that sovereignty in the modern state is more diffused and not absolute. State sovereignty is shared with many other players both state and non-state. Collective security and defence underpins the interdependent nature of regional and world politics. It is in the interest of the states to tame their sovereignty for the betterment of the region. This can only be made possible if states deliberately create strong supra-national institutions (a supra-Leviathan) and actively engage in multi-lateral collective security and defence. Closely tied to this point is the issue of globalisation that has to a great extent de-emphasised the national boundaries of nation states. Globalisation has opened up avenues for benevolent interventions from both nation-states and regional organisations especially in response to security issues that has helped to avert conflict in Africa. Sierra Leonean action to invite ECOMOG was an appreciation by the government of Sierra Leone that it 
needed to play its role of system maintenance. The same applies to South Sudan government of Salva Kiir that invited its neighbours (Kenya, Uganda and others) to send security forces to protect South Sudanese civilians from harm in the on-going civil war that threatens to tear the newest nation-state in the world. In both situations, the nation-states realised that failure to play their individual roles may not necessarily lead to the disintegration of the system, but most likely undermining the stability of the Western and Eastern African systems.

In the South Sudan conflict, there are two antagonists namely President Salva Kiir and former Vice President Riek Machar. The two have been involved in a bitter conflict that mainly revolves around control of the political and economic (oil wealth) spheres. The conflict has been exacerbated by ethnic overtones with the Dinka throwing their lot with President Salva Kiir while the Nuer supporting one of their own, Mr. Machar. More significantly is that the conflict that erupted in December 2013 has not produced an outright winner. This has provided an opportunity for other states to intervene in the conflict with a view to finding a solution to the conflict. The intervention has taken many forms that include quiet diplomacy, evacuation of foreign nationals, and military intervention, among others. Most important has been the action by President Yoweri Museveni of Uganda to send Ugandan troops into South Sudan to fight alongside President Salva Kiir. Like the Sierra Leonean case, it raises a number of questions inter alia: does the government of South Sudan have the capacity to protect its citizen? What happens when the government turns its guns on a section of its population? Does the coming in of Ugandan troops to bolster those of the South Sudan government, an attack on the sovereignty of the state? As is the case with Sierra Leone there is no right answer and it largely depends on the arguments that one is propagating.

\section{Soft States Factor}

The prevalence of conflicts in Africa introduces another dimension to the nexus between state and security. This provides an entry point to the issue of soft state. Conceptually, how the term "soft state" is used has tended to vary with time and even with the perspective used. A major characteristic of a soft state is that authority or power is not centralised but is instead "illegally" divided between the government and other non-state actors. I refer to it as illegal for it is not by choice. There are times that the government appears helpless to control its own destiny and can therefore not guarantee security for its citizens. A case in point is the Democratic Republic of Congo (DRC) under President Joseph Kabila that has experienced many decades of conflict. Some large parts of DRC, particularly North and South Kivu and East DRC, are in the hands of militias and other more organised rebel groups like the M23. It has been alleged by international organizations (mainly United Nations) and national governments (USA and others) that the M23 receives financial and other forms of aid from the Rwanda government of Paul Kagame. The point is that M23 consists of mainly Tutsi refugees that escaped the Rwanda genocide of 1994 and therefore its close ties with the Rwanda government. This alleged association has led to diplomatic stand-off between Rwanda and the USA, among others. In 2013, the M23 rebels agreed to surrender after a number of defeats in the hands of President Kabila's forces. More importantly is that the conflict has been exacerbated by foreign national governments and multinational corporations taking advantage of the DRC government's inability to maintain central command over its vast mineral wealth. It is this weakness that makes the DRC incapable of providing security to its citizens. The same applies to Somalia where the government may claim to be in-charge but in reality large parts of the state are in the hands of militias, bandits and rebel groups that do not own allegiance to the government or state. Sadly some of the illegal groups even have their owe tax systems thereby denying the central government funding. As noted by Cicero (1960) [21], a cardinal duty of the government is to collect taxes with a view to efficient service delivery to the populace. It is also the responsibility of the populace to "give unto Caesar what belongs to Caesar..." The fact that virtual terrorist groups like Al Shabaab have for many years controlled significant areas of Somalia and in addition to having their own elaborate tax system is indicative of a "weak/lame Leviathan" (Callaghy, 1987) [24].

Related to the above is that when some parts of the state exist independent of the central government, it is a manifestation of a declining and decaying state (Young, 1985) [25]. A large percentage of the citizens (if we may call them that) do not need the government in any way in their day-to-day activities. To such, the government does not exist, or if at all, only exists in the figment of their imagination in an abstract form. Hyden (1983) [26] views the Tanzanian state as "weak" for the peasants who form a significant percentage of the population and who do not require the patronage of the state for their survival. The absence of the state in their lives shows that it (state) has failed to spread its tentacles and relevance to all corners of society. The government is therefore "hardly omnipotent” and therein lays its soft nature (Rothchild, 1988) [27]. 


\section{Final Remarks}

In conclusion, Africa is full of weak states that fail to exercise control over society: where it is selfish individuals who exercise control and shape society; where public officials ignore standard operating procedures and laws and instead look for ways of circumventing formal rules and where states do not act autonomously but have surrendered their sovereignty to other entities. It is in line with this that this article argues that it is sometimes futile for African states to insist on sovereignty and pursue national security interests. For Africa to budget for peace instead of conflict there will be a need to limit the unbridled nature of the African to self destruct. As noted by Locke there is enough for everyone, but there is not enough for every man's greed. The cardinal rule for society is to "do unto others as thou would like to do unto thy self". Herein the solution is presented. The state should play its role of security more effectively while appreciating the rights of the individual comes with duties, and it is in the interest of the individual to live in harmony with others. It is Rousseau who argued that it is the responsibility of the state to elevate man from a stupid and limited animal to an intelligent being who is able to co-exist with others. Security is not a role that can be ignored or passed on to another entity, even if it means interfering with the freedom of an individual to prevent harm to others.

\section{References}

[1] Hobbes, T. (2009) Leviathan. Clarendon Press, Oxford.

[2] Nation Reporter (2014) The South Sudan Conflict. Daily Nation Newspaper, 9th April 2014, 8-9.

[3] Augustine, S. (2003) City of God. Bettenson, H., Trans., Penguin Classics, London.

[4] Burke, E. (1955) Reflections on the French Revolution in France. Henry Regnery, Chicago.

[5] Aristotle (1981) The Politics. Penguin, Harmondsworth.

[6] Hobbes, T. (2009) Leviathan. Clarendon Press, Oxford.

[7] Locke, J. (1960) Two Treatise of Civil Government. Laslett, P., Ed., Cambridge University Press, Cambridge.

[8] Hobbes, T. (2009) Leviathan. Clarendon Press, Oxford.

[9] Burke, E. (1955) Reflections on the French Revolution in France. Henry Regnery, Chicago.

[10] Hobbes, T. (2009) Leviathan. Clarendon Press, Oxford.

[11] Machiavelli, N. (1952) The Prince. Mentor Books, New York.

[12] BBC (2014) http://www.bbc.com/news/world-africa-12392062

[13] Karon, T. (2000) The Resistible Rise of Foday Sankoh. Times, 12 May 2000.

[14] Locke, J. (1960) Two Treatise of Civil Government. Edited and an Introduction by Peter Laslett, Cambridge University Press, Cambridge.

[15] Mill, J.S. (1946) On Liberty and Representative Government. McCollum, R.B., Ed., Basil Blackwell, Oxford.

[16] Rousseau, J.J. (1979) The Social Contract. Bloom, A., Trans., Basic Books, New York.

[17] Ilibagiza, I. and Erwin, S. (2007) Left to Tell: One Woman’s Story of Surviving the Rwandan Holocaust. Hay House UK Ltd., London.

[18] Cicero, M.T. (1960) Selected Works (Penguin Classics-No. L99). Penguin Books, London.

[19] Weber, M. (1922) Economy and Society. University of California Press, Berkeley.

[20] Acemoglu, D. and Robinson, J.A. (2013) Why Nations Fail: The Origins of Power, Prosperity and Poverty. Profile Books Ltd., London.

[21] Bodin, J. (1992) On Sovereignty: Six Books of the Commonwealth. Cambridge University Press, Cambridge. http://dx.doi.org/10.1017/CBO9780511802812

[22] Laski, H. (1917) Studies in the Problem of Sovereignty. In: Political Science Quarterly, No. 3, Yale University Press, New Haven, xi-297.

[23] Hegel, G.W.F. (1988) Introduction to the Philosophy of History: With an Appendix from the Philosophy of Right. Hackett Pub. Co. Inc., New York.

[24] Callaghy, T. (1987) The State as Lame Leviathan: The Patrimonial_Administrative State in Africa. In: Ergas, Z., Ed., The African State in Transition, Macmillan Press, London, 423-442.

[25] Young, C. and Turner, T. (1985) The Rise and Decline of the Zairean State. University of Wisconsin Press, Madison. 
[26] Hyden, G. (1983) Beyond Ujamaa in Tanzania. Heinemann, London.

[27] Rothchild, D. (1988) Hegemony and State Softness: Some Variations in Elite Responses. In: Ergas, Z., Ed., The African State in Transition, Macmillan Press, London, 117-148. 
Scientific Research Publishing (SCIRP) is one of the largest Open Access journal publishers. It is currently publishing more than 200 open access, online, peer-reviewed journals covering a wide range of academic disciplines. SCIRP serves the worldwide academic communities and contributes to the progress and application of science with its publication.

Other selected journals from SCIRP are listed as below. Submit your manuscript to us via either submit@scirp.org or Online Submission Portal.
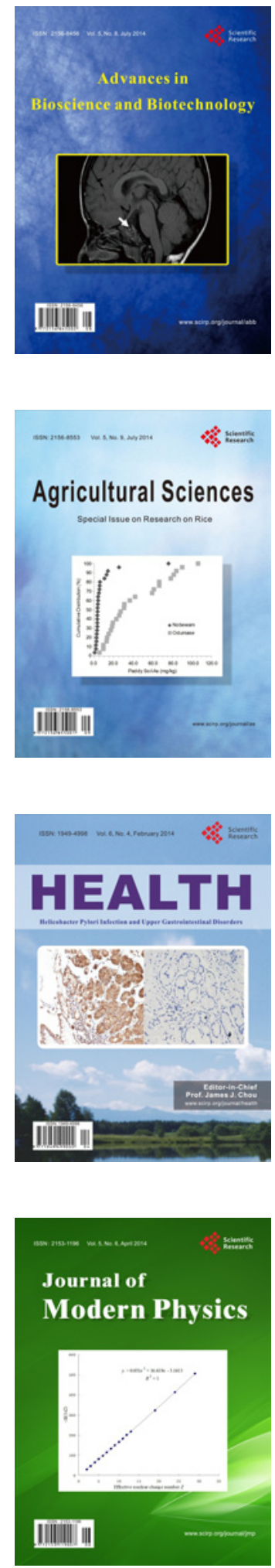
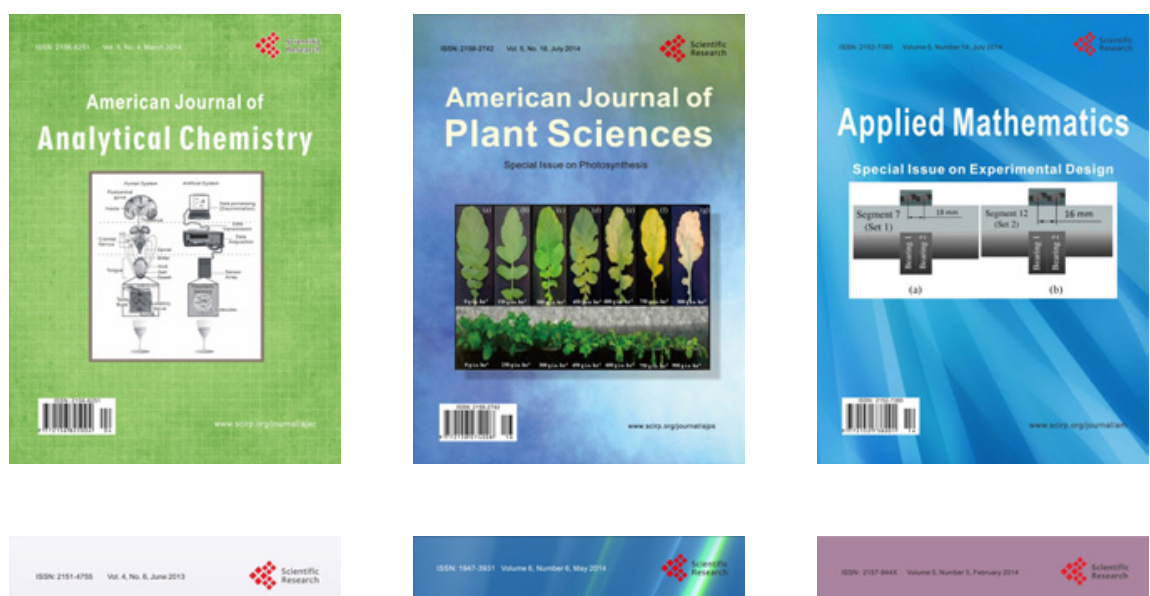

Creative Education
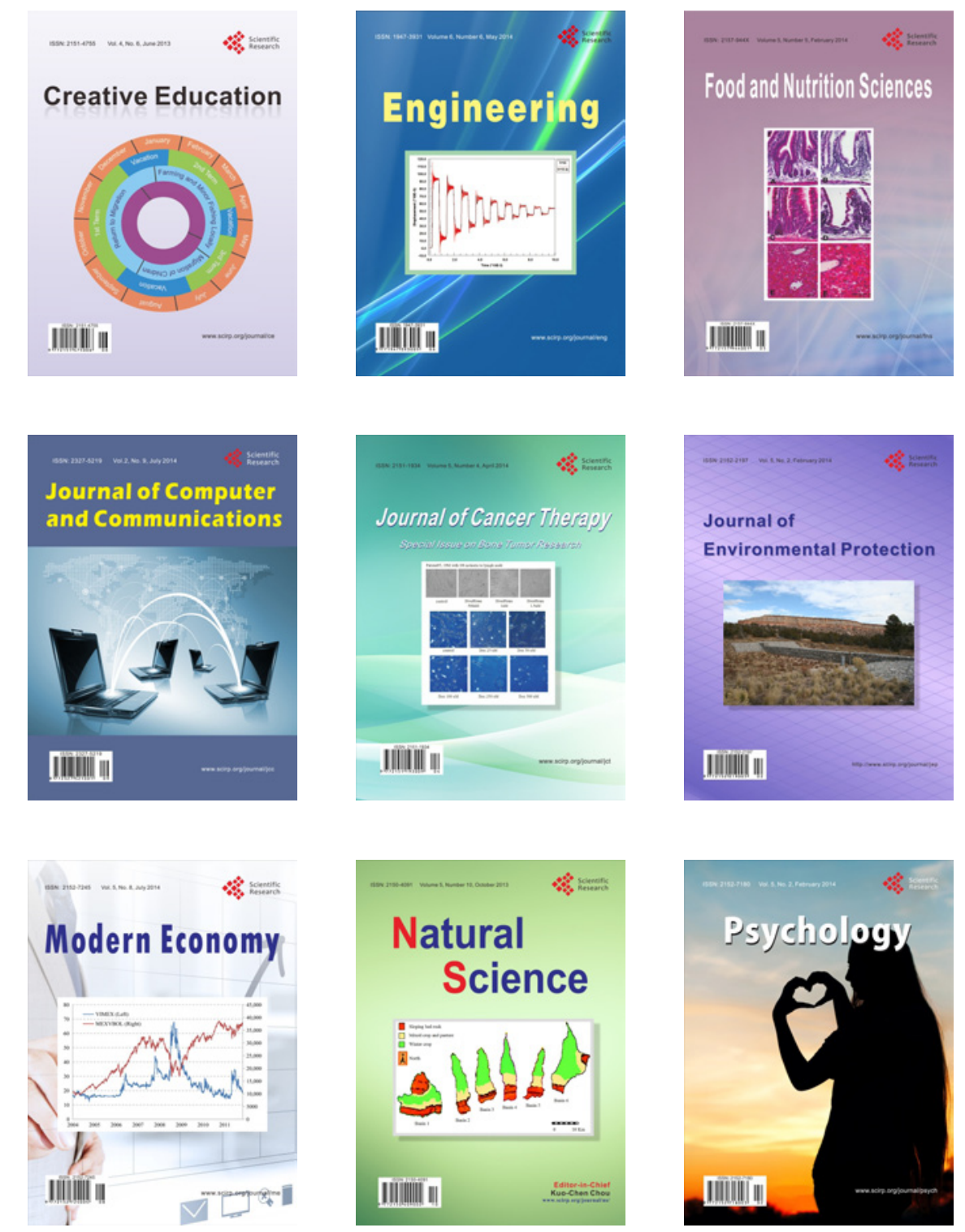